\title{
Effect of Protein Oxidation on the Conformational Properties of Peanut Protein Isolate
}

\author{
Lin Ye, ${ }^{1}$ Yu Liao, ${ }^{1}$ Mouming Zhao, ${ }^{1,2}$ and Weizheng Sun ${ }^{1}$ \\ ${ }^{1}$ College of Light Industry and Food Sciences, South China University of Technology, Guangzhou 510640, China \\ ${ }^{2}$ State Key Laboratory of Pulp and Paper Engineering, South China University of Technology, Guangzhou 510640, China
}

Correspondence should be addressed to Weizheng Sun; fewzhsun@scut.edu.cn

Received 16 July 2013; Revised 6 September 2013; Accepted 6 September 2013

Academic Editor: Hani El-Nezami

Copyright (C) 2013 Lin Ye et al. This is an open access article distributed under the Creative Commons Attribution License, which permits unrestricted use, distribution, and reproduction in any medium, provided the original work is properly cited.

\begin{abstract}
Peanut protein isolate (PPI) was oxidized by peroxyl radicals derived from $2,2^{\prime}$-azobis (2-amidinopropane) dihydrochloride $(\mathrm{AAPH})$, and the conformational properties of oxidized PPI were investigated. Oxidation of PPI resulted in gradual carbonyl generation and free sulfydryl group degradation. The analysis of the maximum emission wavelength indicated change in the tertiary conformation of PPI after oxidation. Lower level oxidation could generate soluble protein aggregates with more flexible structure, while higher level oxidation would induce the formation of insoluble aggregates. Result from dynamic light scattering (DLS) and protein solubility showed that protein aggregation was correlated with protein surface hydrophobicity, indicating that protein oxidation and heat treatment could induce protein aggregation, leading to PPI conformational changes.
\end{abstract}

\section{Instruction}

Peanut, as an important oilseeds in China, India, and other countries, is a potential source of proteins [1]. Protein in peanut can be extracted to produce peanut protein isolate (PPI) as food additive $[2,3]$. In recent years, peanut protein has been receiving increasing attention in food industry due to their unique flavor and amino acid composition [4].

Protein functional properties as an important food processing factors influence food quality. These properties include the water/oil binding, emulsification, foam formation, viscosity, and gelation. They are governed by the conformational properties, especially the intrinsic factors of protein such as their molecular structure and physicochemical characteristics [5].

Protein oxidation has become innovative issues of research in the food chemistry field [6]. Protein was attacked directly by reactive oxygen species (ROS) or indirectly by reaction with the byproducts of lipid peroxidation which leads to the structural modification $[7,8]$. Peanut protein can be also vulnerable to oxidative attack during processing and storage. Physical and chemical changes of peanut proteins during processing have been described in considerable detail $[9,10]$. Some researchers had used various kinds of ROS or byproducts of lipid peroxidation to simulate protein oxidation. They found that protein oxidation affected the conformational and functional properties of food proteins, such as meat protein [11] and soybean protein [12]. However, the effect of protein oxidation on the conformational properties of PPI is rarely investigated. The conformational properties of PPI could affect the nutritional and functional properties of the lipid-enriched food based PPI. A better understanding of the relationship between protein oxidation and their physicochemical, conformational properties can give guidance to rational use of PPI in industry process and storage.

Peroxyl radicals (ROO*) are a kind of free radicals generated from lipid peroxidation and the key chainpropagating species. Reaction of peroxyl radicals constitutes propagation process in protein chain oxidation reactions by abstracting hydrogen atoms from protein [13]. Thermal decomposition of $2,2^{\prime}$-azobis (2-amidinopropane) dihydrochloride (AAPH) can generate peroxyl radicals (ROO*) at a known and constant rate under the stable temperature of $37^{\circ} \mathrm{C}$ and upon their concentration [14]. Therefore, AAPHderived peroxyl radicals as the byproduct of lipid peroxidation were used to evaluate the effect of protein oxidation on the conformational properties of PPI in this work. 


\section{Materials and Methods}

2.1. Samples and Materials. Low temperature defatted peanut flour was purchased from Tianshen Bioprotein Co., Ltd. (Linyi, Shandong, China). 2,2'-azobis (2-amidinopropane) dihydrochloride (AAPH) was purchased from Sigma-Aldrich (St. Louis, MO, USA). All other chemicals were of analytical reagent grade.

2.2. PPI Preparation. PPI was prepared according to the method with a slight modification [2]. Defatted peanut flour was mixed with 20-fold deionized water, and the $\mathrm{pH}$ of the dispersion was adjusted to 8.0 with $2 \mathrm{M} \mathrm{NaOH}$. The mixture was gently stirred at $25^{\circ} \mathrm{C}$ for $2 \mathrm{~h}$ and then centrifuged at $8,000 \mathrm{~g}$ for $30 \mathrm{~min}$ at $20^{\circ} \mathrm{C}$ using a CR22G high-speed centrifuge (Hitachi Co., Tokyo, Japan). The supernatant was adjusted to $\mathrm{pH} 4.5$ with $2 \mathrm{M} \mathrm{HCl}$ and then centrifuged at $5,000 \mathrm{~g}$ for $20 \mathrm{~min}$ at $20^{\circ} \mathrm{C}$. The precipitate was then redissolved in 5-fold deionized water and adjusted to $\mathrm{pH} 7.0$ with $2 \mathrm{M} \mathrm{NaOH}$. This solution was freeze-dried to produce PPI product (control). The protein content of PPI (88.0 \pm $1.0 \%$ ) was determined by a rapid $\mathrm{N}$ cube nitrogen analyser (Elementar Analysensysteme, Hanau, Germany).

2.3. PPI Oxidation. Oxidized PPI was prepared according to the method with a slight modification $[12,15]$. PPI solution was adjusted to $25 \mathrm{mg} / \mathrm{mL}$ (containing $0.5 \mathrm{mg} / \mathrm{mL}$ sodium azide) by $10 \mathrm{mM}$ sodium phosphate buffer $(\mathrm{pH} 7.4)$ and mixed with a serial concentration of AAPH $(0,0.04,0.2$, $0.5,1,3$, and $5 \mathrm{mM}$ ). The above solutions were incubated by continuous shaking under air at $37^{\circ} \mathrm{C}$ in dark for $24 \mathrm{~h}$. The solutions were cooled to $4^{\circ} \mathrm{C}$ by ice-bathing to stop the reaction and then centrifuged at $8,000 \mathrm{~g}$ for $15 \mathrm{~min}$ at $4^{\circ} \mathrm{C}$. The supernatant was dialyzed against deionized water at $4^{\circ} \mathrm{C}$ for $72 \mathrm{~h}$ to remove residual AAPH and salt. Oxidized PPI was obtained by freeze-drying and stored at $4^{\circ} \mathrm{C}$ until use.

2.4. Protein Carbonyl Measurement. Protein carbonyl was detected according to the method of $\mathrm{Wu}$ et al. [15] with a slight modification [12]. Protein concentration of PPI was determined by Biuret method using bovine serum albumin (BSA) as a standard. The results were expressed as nmol of carbonyl groups per milligram of soluble protein with molar extinction coefficient of $22,000 \mathrm{M}^{-1} \mathrm{~cm}^{-1}$.

2.5. Free Sulfydryl Groups Measurement. Contents of free sulfydryl groups (free SH) in the PPI were evaluated by Beveridge's method [16]. Protein concentration of PPI was evaluated by Biuret method. The results were expressed as nmol of $\mathrm{SH}$ per milligram of soluble protein with molar extinction coefficient of $13,600 \mathrm{M}^{-1} \mathrm{~cm}^{-1}$.

2.6. Particle Size Distribution of PPI. Particle size distribution was detected by dynamic light scattering (DLS) by a Zetasizer Nano-ZS instrument (Malvern Instruments, Worcestershire, UK). PPI solution was adjusted to $0.2 \mathrm{mg} / \mathrm{mL}$ by $10 \mathrm{mM}$ sodium phosphate buffer ( $\mathrm{pH}$ 7.0). The suspension was magnetic stirred and centrifuged at $10,000 \mathrm{~g}$ for $10 \mathrm{~min}$. The supernatant was filtered through cellulose acetate membranes with pore size of $0.45 \mu \mathrm{m}$. Then $0.8 \mathrm{~mL}$ PPI solution was transferred to a square cuvette for DLS measurement. Results were analyzed by Dispersion Technology Software (DTS) versison 4.20 (Malvern Instruments Ltd., Worcestershire, UK).

2.7. Measurement of Protein Surface Hydrophobicity. Protein surface hydrophobicity was determined using ANS-, according to the method [17]. In brief, a series of dilutions of PPI $(0.05,0.1$, and $0.2,0.5,1.0,2.0 \mathrm{mg} / \mathrm{mL})$ were made with $10 \mathrm{mM}$ phosphate buffer ( $\mathrm{pH} 7.0)$. Each PPI solution $(4 \mathrm{~mL})$ was reacted with $20 \mu \mathrm{L}$ of stock solutions of $8 \mathrm{mM}$ ANS-. Samples were mixed using the vortex mixer for about $5 \mathrm{~s}$. Fluorescence intensity (FI) was measured at wavelengths of $390 \mathrm{~nm}$ (excitation) and $470 \mathrm{~nm}$ (emission) at $20 \pm 0.5^{\circ} \mathrm{C}$ using a RF-5301 PC fluorophotometer (Shimadzu Co., Kyoto, Japan), with a constant excitation and emission slit of $5 \mathrm{~nm}$. The FI attributed to protein in buffer of each sample was subtracted. The initial slope of the FI versus protein concentration plot was calculated by linear regression analysis and used as an index of surface hydrophobicity.

2.8. Intrinsic Fluorescence Emission Spectra. Intrinsic emission fluorescence spectra of protein samples were evaluated using the fluorescence spectrophotometer (F7000, HITACHI, Tokyo, Japan). PPI solutions $(0.2 \mathrm{mg} / \mathrm{mL})$ were made by $10 \mathrm{mM}$ phosphate buffer ( $\mathrm{pH}$ 7.0). PPI solutions were excited at $290 \mathrm{~nm}$, and emission spectra were recorded from 300 to $400 \mathrm{~nm}$ at a constant slit of $5 \mathrm{~nm}$ for both excitation and emission. The maximum emission wavelength of the spectra was recorded for analysis.

2.9. Protein Solubility. PPI dispersions in deionised water $(1 \%, \mathrm{w} / \mathrm{v})$ were stirred magnetically for $30 \mathrm{~min}$. The $\mathrm{pH}$ was adjusted to 7.0 with $0.5 \mathrm{M} \mathrm{HCl}$ or $0.5 \mathrm{M} \mathrm{NaOH}$. After stirring, the $\mathrm{pH}$ was readjusted if necessary. Then the dispersions were centrifuged at $12,000 \mathrm{~g}$ for $20 \mathrm{~min}$ at $20^{\circ} \mathrm{C}$. After appropriate dilution, the protein content of the supernatants was determined by Lowry's method using BSA as the standard. The protein solubility was expressed as grams of soluble protein per $100 \mathrm{~g}$ of protein.

2.10. Statistics Analysis. Statistical calculations were performed using the statistical package SPSS 11.5 (SPSS Inc., Chicago, IL, USA) for one-way ANOVA. Least-squares difference was used for comparison of mean values among treatments and to identify significant differences $(P<0.05)$ among treatments. All the data were expressed as means \pm standard deviations of triplicate determinations.

\section{Results and Discussion}

3.1. Characterization of Oxidized PPI. Carbonylation is generally recognized as one of the most remarkable chemical modifications in oxidized proteins [6]. Protein carbonyl content is one of the most widely used methods for evaluating the extent of protein oxidation. Effect of AAPH on total 
TABLE 1: Protein carbonyl and free sulphydryl of PPI incubated with increasing concentration of AAPH for $24 \mathrm{~h}$ at $37^{\circ} \mathrm{C}$.

\begin{tabular}{lcc}
\hline AAPH $(\mathrm{mM})$ & Carbonyl $(\mathrm{nmol} / \mathrm{mg})$ & Free SH $(\mathrm{nmol} / \mathrm{mg})$ \\
\hline Control & $3.93 \pm 0.13^{\mathrm{a}}$ & $4.82 \pm 0.10^{\mathrm{e}, \mathrm{f}}$ \\
0 & $4.12 \pm 0.09^{\mathrm{b}}$ & $4.95 \pm 0.07^{\mathrm{f}}$ \\
0.04 & $4.19 \pm 0.06^{\mathrm{b}}$ & $4.69 \pm 0.06^{\mathrm{e}}$ \\
0.20 & $4.21 \pm 0.08^{\mathrm{b}}$ & $4.35 \pm 0.08^{\mathrm{d}}$ \\
0.50 & $4.16 \pm 0.06^{\mathrm{b}}$ & $3.98 \pm 0.10^{\mathrm{c}}$ \\
1.00 & $4.52 \pm 0.11^{\mathrm{c}}$ & $3.74 \pm 0.08^{\mathrm{b}}$ \\
3.00 & $4.57 \pm 0.11^{\mathrm{c}}$ & $3.68 \pm 0.13^{\mathrm{b}}$ \\
5.00 & $4.77 \pm 0.12^{\mathrm{d}}$ & $3.18 \pm 0.09^{\mathrm{a}}$ \\
\hline
\end{tabular}

Values in the same row followed by different letters are significantly different $(P<0.05)$.

carbonyl content of PPI is given in Table 1 . The carbonyl level of PPI (control) was $3.93 \mathrm{nmol} / \mathrm{mg}$ protein. This value was higher than porcine myofibrillar protein [18] and soybean protein [15], but lower than soy-protein isolates [19]. These discrepancies might be due to the difference in raw material used. The addition of the oxidizing agent produced an increase in carbonyl content following a concentrationdependent manner. The carbonyl content of PPI $(0 \mathrm{mM})$ increased significantly $(P<0.05)$ after maintaining the samples at $37^{\circ} \mathrm{C}$ for $24 \mathrm{~h}$. This phenomenon might be due to the time-temperature combinations of $37^{\circ} \mathrm{C} / 24 \mathrm{~h}$ [11]. Heat treatment could produce a significant increase in protein carbonyl content [20]. No significant difference of PPI carbonyl content was observed until AAPH concentration reached 1.0 mM. Protein oxidation can alter their secondary and tertiary structures, leading to changes in physical properties of proteins [15].

The content of sulfydryl groups (SH) is another general indicator of protein oxidation. $\mathrm{SH}$ can be oxidized to reversible form (protein disulfide and sulfenic acid) or irreversible form (sulfinic and sulfonic acid) in different oxidative environments [21]. In addition, cysteine residues were the most susceptible amino acid residues of proteins to be oxidized, but the carbonyl contents could not reflect oxidation state of cysteine residues. Effect of AAPH on the levels of free SH of PPI is shown in Table 1. The addition of the AAPH resulted in a significant decline $(P<0.05)$ in free SH. It was remarkable that incubation with $5.0 \mathrm{mM}$ AAPH resulted in $43 \%$ loss of free $\mathrm{SH}$. Cysteine residues and disulphide bonds play an important role in the structure of proteins [22]. Therefore, loss of free sulfydryl groups induced structural changes of oxidized PPI.

3.2. Analysis of Protein Surface Hydrophobicity. Surface hydrophobicity could monitor subtle changes in chemical and physical states of protein and be used as an important parameter to evaluate protein structural changes [8]. Effect of AAPH on surface hydrophobicity of PPI is shown in Figure 1. Compared to control, surface hydrophobicity of PPI at $0 \mathrm{mM}$ increased significantly $(P<0.05)$. This phenomenon might be also due to the time-temperature combinations of $37^{\circ} \mathrm{C} / 24 \mathrm{~h}$. Heat treatment can induce an

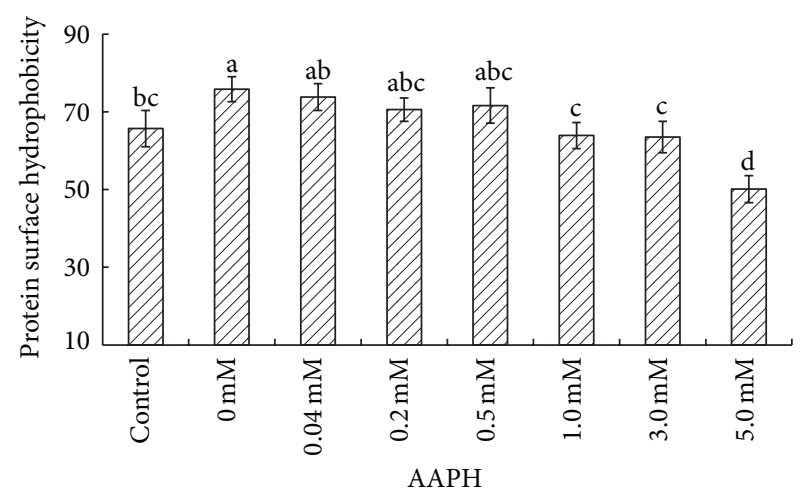

FIGURE 1: Effect of AAPH on the surface hydrophobicity of PPI. Values in a column followed by different letters are significantly different $(P<0.05)$.

increase in surface hydrophobicity [23]. Oxidized PPI with increase of AAPH concentration led to a gradual decrease in surface hydrophobicity. This phenomenon can be explained as combined effects of conformational change of PPI. Protein aggregation via hydrophobic association, covalent modification of exposed hydrophobic residues (tryptophan residue), and introduction of new hydrophilic components (protein carbonyls groups) were related to the decline of surface hydrophobicity [15]. This result was in agreement with the reports $[15,24]$ that protein oxidation resulted in changes of protein surface hydrophobicity. The hydrophobic interactions are considered to play important roles in the functional properties of food proteins. Therefore, surface hydrophobicity could induce changes in conformational properties of oxidized PPI.

3.3. Intrinsic Fluorescence Emission Spectra. Reactive oxygen species (ROS) also could result in oxidation of tryptophan residues of proteins [25]. Tryptophan residues can emit fluorescence in the range $300-400 \mathrm{~nm}$ when excited at $290 \mathrm{~nm}$ [12]. Tryptophan maximum fluorescence emission wavelength can denote the relative position of the tryptophan residues within proteins and commonly used as a marker for detecting protein conformational change [26]. As shown in Figure 2, the maximum emission wavelength increased appreciably after maintaining the samples at $37^{\circ} \mathrm{C}$ for $24 \mathrm{~h}$. During oxidation, the maximum emission wavelength increased gradually from 329.0 to $329.8 \mathrm{~nm}$ between 0 and $0.20 \mathrm{mM}$ AAPH and then decreased to 328.6 and $327.7 \mathrm{~nm}$, respectively, at 3.00 and $5.00 \mathrm{mM} \mathrm{AAPH}$. Shifts of fluorescence emission to longer wavelengths (red shift) indicate that chromophores (tryptophan residues) become more exposed to a hydrophilic environment while shorter wavelength (blue shift) to a hydrophobic environment [26]. Protein oxidation could induce both red shift and blue shift of the maximum emission wavelength of tryptophan fluorescent spectrum in previous researches $[8,15,27]$. Protein oxidation could lead to increase in structural flexibility, and some initially protected backbone amide groups were exposed [28]. At lower oxidizing agent concentration, PPI might firstly 


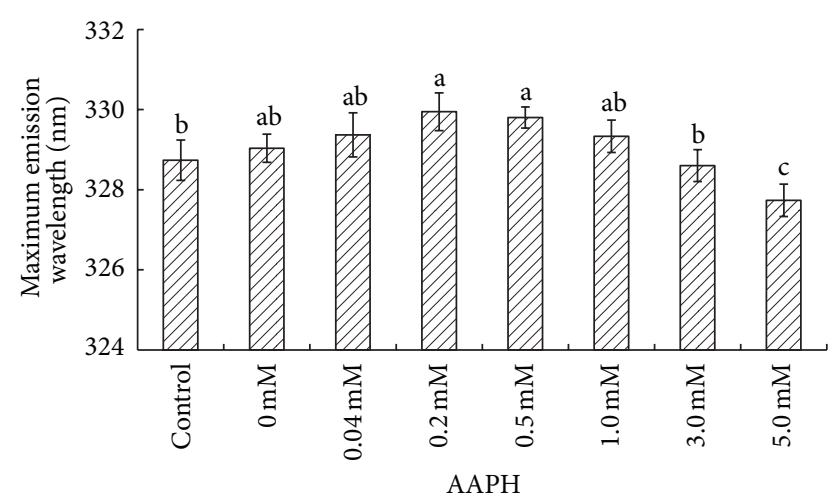

FIgURE 2: Maximum emission wavelength of PPI incubated with AAPH.

expose more tryptophan residues to the protein surface. With the further oxidation, some of the exposed hydrophobic groups participated in hydrophobic interactions, resulting in formation of insoluble aggregates.

3.4. Oxidation Aggregation of PPI. Dynamic light scattering (DLS) is a quantitative, sensitive, and powerful method to monitor the formation of protein aggregates. Particle size distributions of AAPH modified PPI are shown in Figure 3. After incubation at $37^{\circ} \mathrm{C}$ for $24 \mathrm{~h}$, the peak of particle size distributions $(0 \mathrm{mM})$ shifted to larger particles. Addition of oxidizing agent $0.04 \mathrm{mM}$ produced an increase in the volume of large particles but a decrease in volume of small particles. When at the concentration $0.20 \mathrm{mM}$, the particle size distributions became similar to sample of $0 \mathrm{mM}$. Oxidized PPI shifted to larger molecule within AAPH $0.50 \mathrm{mM}$. At higher AAPH concentration (1.00-5.00 mM), compared with $0.50 \mathrm{mM}$, the peak of particle size distributions shifted to small particles.

Only soluble component of sample was investigated in DLS [12]. Results indicated that oxidized PPI at low concentration of oxidant reagent $(\mathrm{AAPH} \leq 0.50 \mathrm{mM})$ could lead to form PPI soluble aggregates. Higher level oxidation could promote insoluble component formation and cleavage of peptide bonds by peroxyl radicals $[11,29]$. Therefore, between 1.00 and $5.00 \mathrm{mM}$ AAPH, some larger soluble aggregates broke into smaller soluble peptides, while some shifted to insoluble components through covalent and noncovalent interaction (hydrophobic interactions). Insoluble components were removed by centrifugation. Results from analysis of protein surface hydrophobicity and maximum emission wavelength further confirmed this process (Figures 1 and 2). This was in agreement with the previous studies [30, 31].

Aggregation can lead to loss of protein solubility. Protein solubility at $\mathrm{pH} 7.0$ was obtained to evaluate formation of insoluble aggregates indirectly in this work. As shown in Figure 4, protein solubility first increased with slight increase significantly $(P<0.05)$ at low concentration of oxidant reagent $(\mathrm{AAPH} \leq 0.50 \mathrm{mM})$ and then decreased between 1.00 and $5.00 \mathrm{mM}$ AAPH. Not only nonpolar amino acid groups but also some polar amino acid groups, buried inside

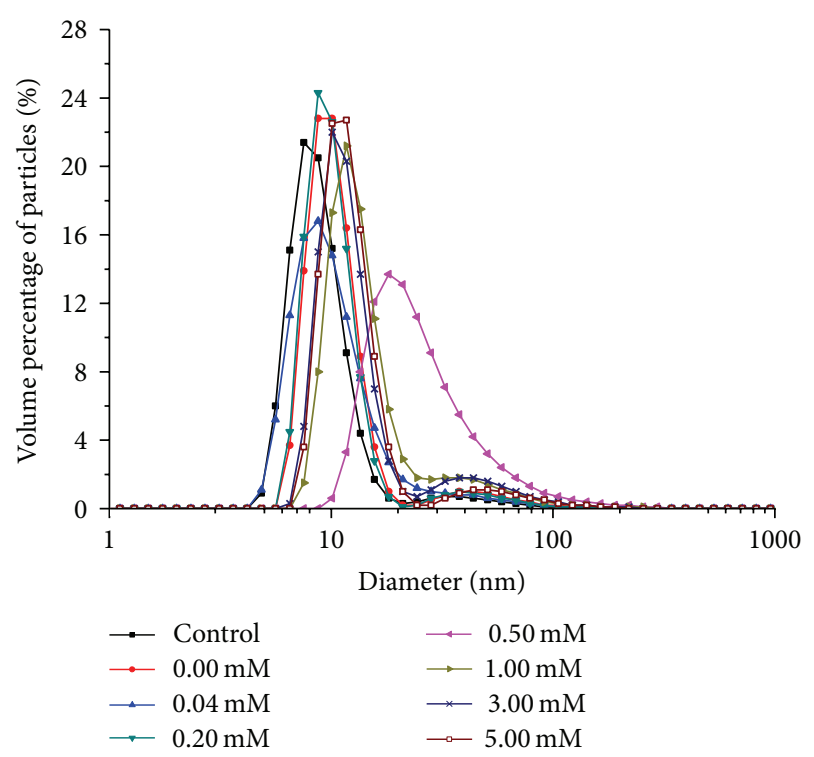

FIgURE 3: Particle size distribution change of PPI incubated with AAPH.

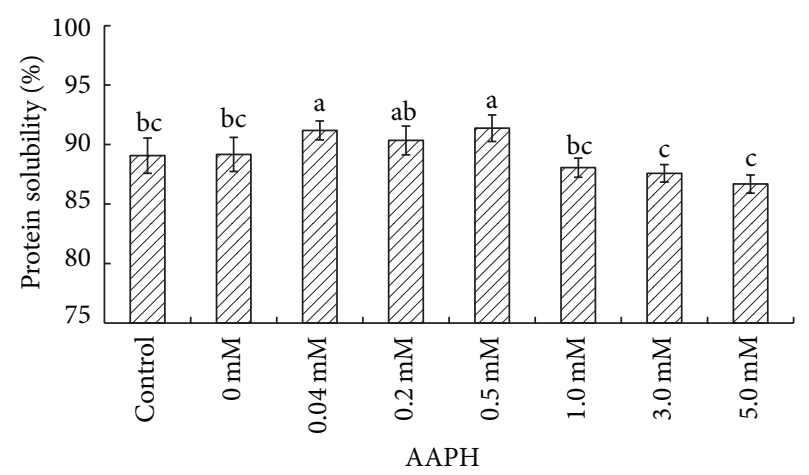

FIGURE 4: Effect of AAPH on protein solubility of PPI. Values in a column followed by different letters are significantly different $(P<$ 0.05).

protein molecules, could be exposed on the surface of protein molecules after treatment. These exposed polar amino acids may interact with water molecules through hydrogen bonds and electrostatic interactions, resulting in increased protein solubility. In addition, the intimate relationship of solubility and surface hydrophobicity reinforces the importance of hydrophobic interactions in protein aggregationinsolubilization process. The surface hydrophobicity is determined by the soluble proteins. So the coexistence of high protein solubility with high surface hydrophobicity might be due to two factors: (a) the protein species undergoing aggregation are the more hydrophobic, so that only the hydrophilic ones remain soluble; (b) as the proteins aggregate, they hide or occlude the hydrophobic zones, leaving part of the proteins as soluble aggregates of low surface hydrophobicity. The increase at lower level oxidation might arise from the more soluble aggregates formed. Further oxidation induced formation of insoluble components contributed to the decreased 
solubility. This result confirmed the analysis of DLS. The modification of lateral chains of amino acid residues responsible for protein repulsion-attraction phenomena induces a loss of surface activity and hence decreases their solubility. This was in agreement with above results of protein carbonyl (Table 1) and surface hydrophobicity (Figure 1).

\section{Conclusions}

Oxidation could alter the conformational properties of peanut protein isolate. PPI oxidation by peroxyl radicals induced carbonyl generation and free sulfydryl group degradation. Changes in the particle size distributions and protein solubility showed that protein oxidation resulted in soluble or insoluble PPI aggregates depending upon the AAPH concentration. Further work will be carried out to evaluate the functional properties of oxidized PPI.

\section{Acknowledgments}

The authors are grateful to by the National High Technology Research and Development Program of China (863 Program) (no. 2013AA102201), the National Science-Technology Supporting Project for 12th Five-Year Plan (2012BAD37B08), and the National Natural Science Foundation of China (no. 31171783) for their financial supports.

\section{References}

[1] S. N. Jamdar, V. Rajalakshmi, M. D. Pednekar, F. Juan, V. Yardi, and A. Sharma, "Influence of degree of hydrolysis on functional properties, antioxidant activity and ACE inhibitory activity of peanut protein hydrolysate," Food Chemistry, vol. 121, no. 1, pp. 178-184, 2010.

[2] Y. Liu, G. Zhao, M. Zhao, J. Ren, and B. Yang, "Improvement of functional properties of peanut protein isolate by conjugation with dextran through Maillard reaction," Food Chemistry, vol. 131, no. 3, pp. 901-906, 2012.

[3] X. Dong, M. Zhao, J. Shi et al., "Effects of combined highpressure homogenization and enzymatic treatment on extraction yield, hydrolysis and function properties of peanut proteins," Innovative Food Science and Emerging Technologies, vol. 12, no. 4, pp. 478-483, 2011.

[4] S. K. Ghatak and K. Sen, "Peanut proteins: applications, ailments and possible remediation," Journal of Industrial and Engineering Chemistry, vol. 19, no. 2, pp. 369-374, 2013.

[5] J. Yu, M. Ahmedna, and I. Goktepe, "Peanut protein concentrate: production and functional properties as affected by processing," Food Chemistry, vol. 103, no. 1, pp. 121-129, 2007.

[6] M. Estévez, "Protein carbonyls in meat systems: a review," Meat Science, vol. 89, no. 3, pp. 259-279, 2011.

[7] E. Shacter, "Quantification and significance of protein oxidation in biological samples," Drug Metabolism Reviews, vol. 32, no. 34, pp. 307-326, 2000.

[8] W. Sun, M. Zhao, B. Yang, H. Zhao, and C. Cui, "Oxidation of sarcoplasmic proteins during processing of Cantonese sausage in relation to their aggregation behaviour and in vitro digestibility," Meat Science, vol. 88, no. 3, pp. 462-467, 2011.

[9] K. Mcwatters and M. R. Holmes, "Salt concentration, pH, and flour concentration effects on nitrogen solubility and emulsifying properties of peanut flour," Journal of Food Science, vol. 44, no. 3, pp. 765-769, 1979.

[10] N. J. Neucere, "Effect of heat on peanut proteins. I. Solubility properties and immunochemical-electrophoretic modifications," Journal of Agricultural and Food Chemistry, vol. 20, no. 2, pp. 252-255, 1972.

[11] W. Sun, F. Zhou, D. Sun, and M. Zhao, "Effect of oxidation on the emulsifying properties of myofibrillar proteins," Food and Bioprocess Technology, vol. 6, no. 7, pp. 1703-1712, 2013.

[12] N. Chen, M. Zhao, W. Sun, J. Ren, and C. Cui, "Effect of oxidation on the emulsifying properties of soy protein isolate," Food Research International, vol. 52, no. 1, pp. 26-32, 2013.

[13] E. R. Stadtman and R. L. Levine, "Free radical-mediated oxidation of free amino acids and amino acid residues in proteins," Amino Acids, vol. 25, no. 3-4, pp. 207-218, 2003.

[14] S. Gieseg, S. Duggan, and J. M. Gebicki, "Peroxidation of proteins before lipids in U937 cells exposed to peroxyl radicals," Biochemical Journal, vol. 350, no. 1, pp. 215-218, 2000.

[15] W. Wu, C. Zhang, X. Kong, and Y. Hua, "Oxidative modification of soy protein by peroxyl radicals," Food Chemistry, vol. 116, no. 1, pp. 295-301, 2009.

[16] T. Beveridge, S. Toma, and S. Nakai, "Determination of SHand SS-groups in some food proteins using Ellman's reagent," Journal of Food Science, vol. 39, no. 1, pp. 49-51, 1974.

[17] C. A. Haskard and E. C. Y. Li-Chan, "Hydrophobicity of bovine serum albumin and ovalbumin determined using uncharged (PRODAN) and anionic (ANS-) fluorescent probes," Journal of Agricultural and Food Chemistry, vol. 46, no. 7, pp. 2671-2677, 1998.

[18] W. Sun, F. Zhou, M. Zhao, B. Yang, and C. Cui, "Physicochemical changes of myofibrillar proteins during processing of Cantonese sausage in relation to their aggregation behaviour and in vitro digestibility," Food Chemistry, vol. 129, no. 2, pp. 472-478, 2011.

[19] G. Liu, Y. L. Xiong, and D. A. Butterfield, "Chemical, physical, and gel-forming properties of oxidized myofibrils and wheyand soy-protein isolates," Journal of Food Science, vol. 65, no. 5, pp. 811-818, 2000.

[20] V. Santé-Lhoutellier, T. Astruc, P. Marinova, E. Greve, and P. Gatellier, "Effect of meat cooking on physicochemical state and in vitro digestibility of myofibrillar proteins," Journal of Agricultural and Food Chemistry, vol. 56, no. 4, pp. 1488-1494, 2008.

[21] P. Eaton, "Protein thiol oxidation in health and disease: techniques for measuring disulfides and related modifications in complex protein mixtures," Free Radical Biology and Medicine, vol. 40, no. 11, pp. 1889-1899, 2006.

[22] R. W. Visschers and H. H. J. de Jongh, "Bisulphide bond formation in food protein aggregation and gelation," Biotechnology Advances, vol. 23, no. 1, pp. 75-80, 2005.

[23] L. P. Voutsinas, E. Cheung, and S. Nakai, "Relationships of hydrophobicity to emulsifying properties of heat denatured proteins," Journal of Food Science, vol. 48, no. 1, pp. 26-32, 1983.

[24] J. H. Liang, "Fluorescence due to interactions of oxidizing soybean oil and soy proteins," Food Chemistry, vol. 66, no. 1, pp. 103-108, 1999.

[25] Y. S. Ma, C. C. Chao, and E. R. Stadtman, "Oxidative modification of glutamine synthetase by 2,2 '-azobis(2-amidinopropane) dihydrochloride," Archives of Biochemistry and Biophysics, vol. 363, no. 1, pp. 129-134, 1999. 
[26] M. Keerati-u-rai, M. Miriani, S. Iametti, F. Bonomi, and M. Corredig, "Structural changes of soy proteins at the oil-water interface studied by fluorescence spectroscopy," Colloids and Surfaces B, vol. 93, pp. 41-48, 2012.

[27] K. Viljanen, R. Kivikari, and M. Heinonen, "Protein-lipid interactions during liposome oxidation with added anthocyanin and other phenolic compounds," Journal of Agricultural and Food Chemistry, vol. 52, no. 5, pp. 1104-1111, 2004.

[28] S. Saeed, D. Gillies, G. Wagner, and N. K. Howell, "ESR and NMR spectroscopy studies on protein oxidation and formation of dityrosine in emulsions containing oxidised methyl linoleate," Food and Chemical Toxicology, vol. 44, no. 8, pp. 13851392, 2006.

[29] M. J. Davies, "The oxidative environment and protein damage," Biochimica et Biophysica Acta, vol. 1703, no. 2, pp. 93-109, 2005.

[30] W. Wu, Y. Hua, Q. Lin, and H. Xiao, "Effects of oxidative modification on thermal aggregation and gel properties of soy protein by peroxyl radicals," International Journal of Food Science and Technology, vol. 46, no. 9, pp. 1891-1897, 2011.

[31] Y. Huang, Y. Hua, and A. Qiu, "Soybean protein aggregation induced by lipoxygenase catalyzed linoleic acid oxidation," Food Research International, vol. 39, no. 2, pp. 240-249, 2006. 

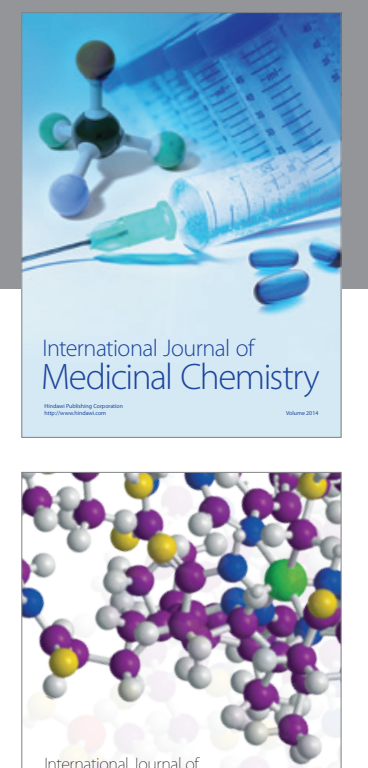

\section{Carbohydrate} Chemistry

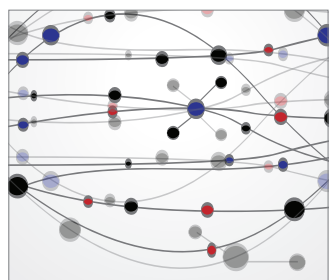

The Scientific World Journal
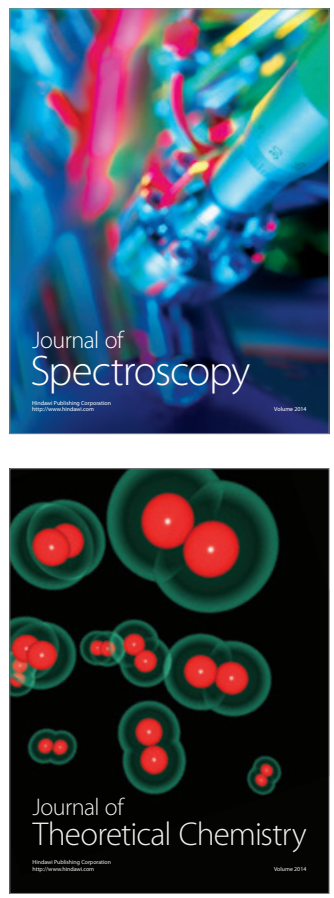
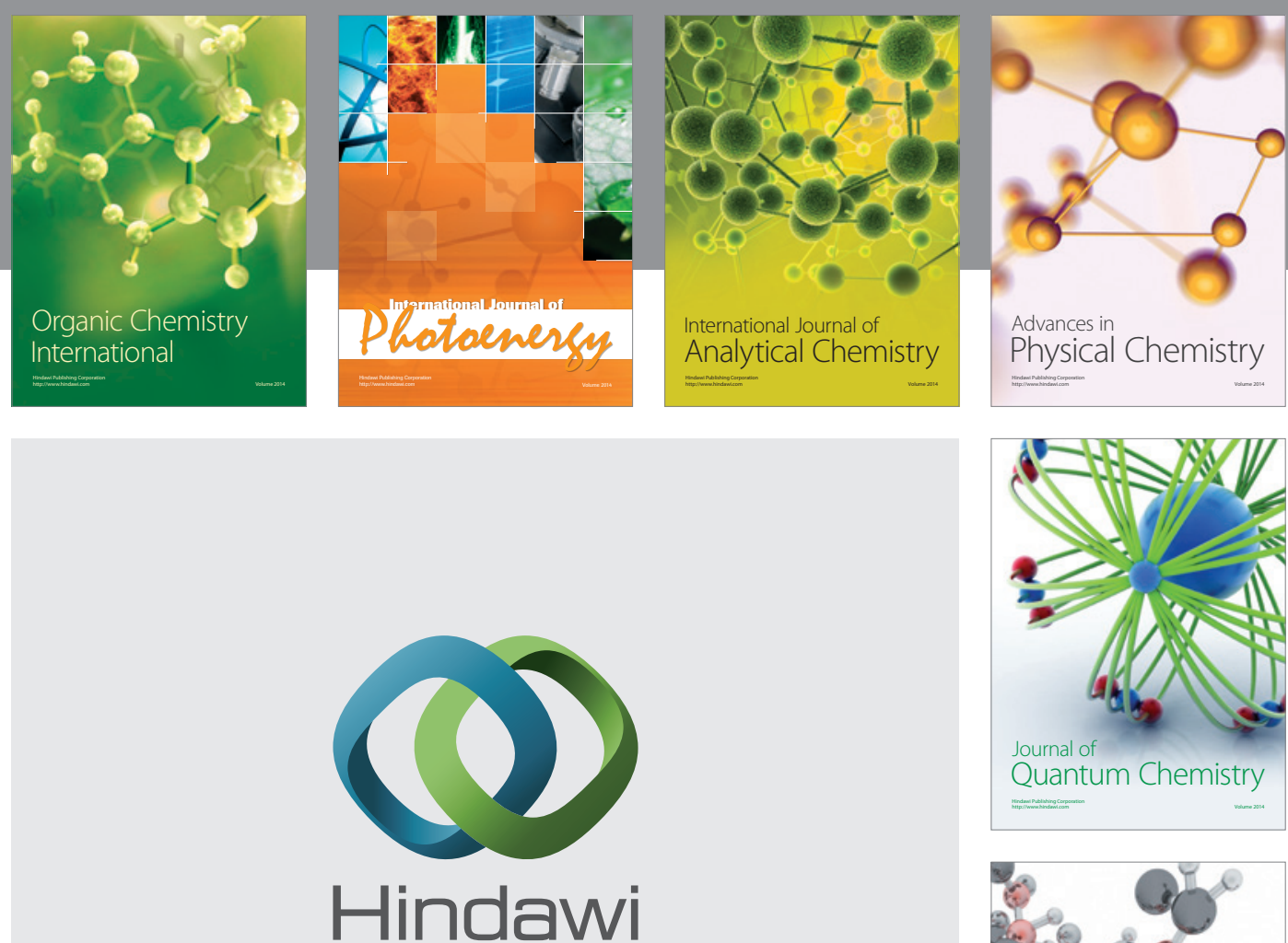

Submit your manuscripts at

http://www.hindawi.com

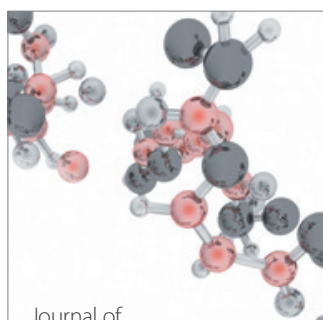

Analytical Methods

in Chemistry

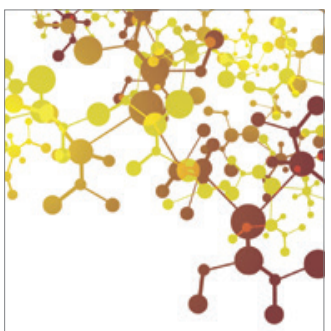

Journal of

Applied Chemistry

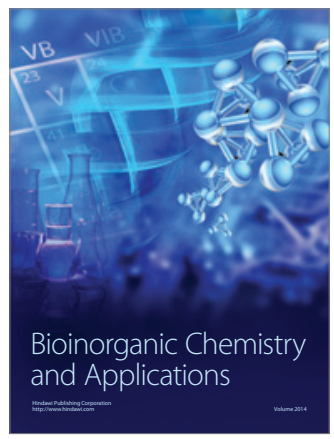

Inorganic Chemistry
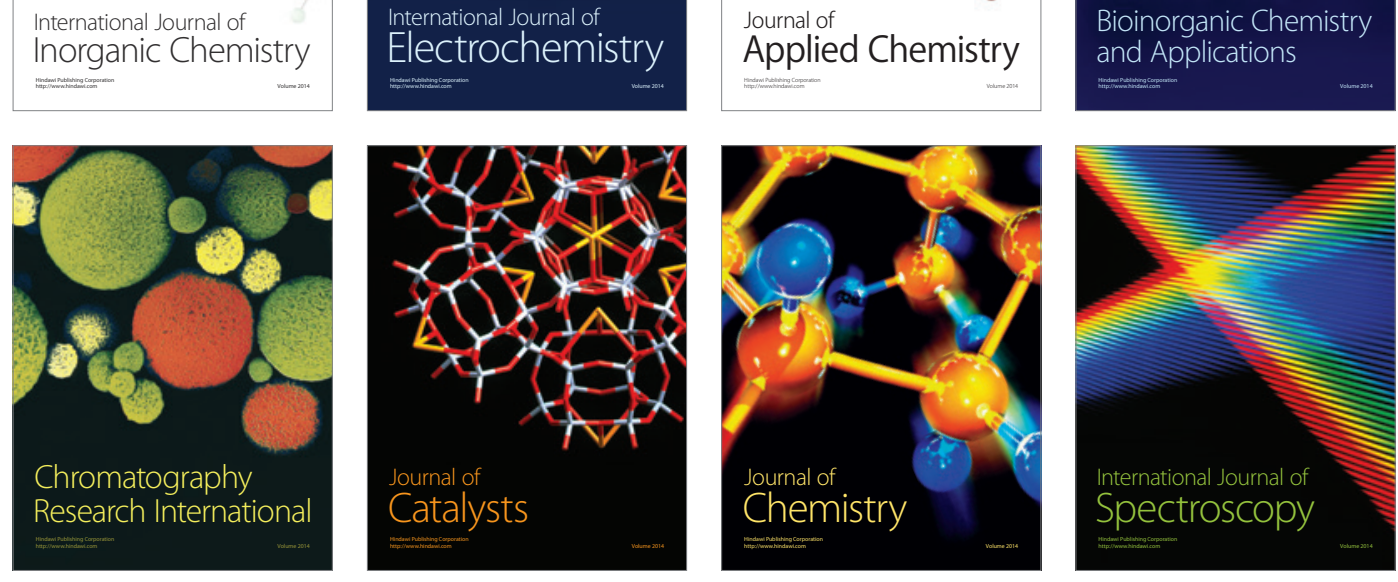